\title{
Purification and characterization of polyphenol oxidase from purslane
}

\author{
Reyhan GUL GUVEN ${ }^{1 \star}$, Kemal GUVEN $^{2}$, Fatma MATPAN BEKLER ${ }^{2}$, Omer ACER ${ }^{2}$, Hüseyin ALKAN ${ }^{3}$, \\ Mehmet DOGRU ${ }^{1}$
}

\begin{abstract}
The polyphenol oxidase (PPO) is an enzyme that is responsible for the enzymatic browning of fruits and vegetables. This is generally undesired process and need to be prevented in food technology. PPO from purslane was purified, characterised and the kinetic parameters for three substrates namely, catechol, L-Dopa and 4-methylcatechol were determined. The optimum pH and temperature values were found to be $\mathrm{pH} 7.0$ and $50^{\circ} \mathrm{C}$, respectively using the catechol as substrate. The apparent molecular weight of the PPO from purslane was determined as high as $163 \mathrm{kDa}$ by partially denaturing SDS-PAGE. Moreover, the inhibition kinetics of the purified PPO were determined, using both synthetic and natural inhibitors. Among inhibitors tested, ascorbic acid was the most effective inhibitor with the lowest $K i$ value of $0.36 \mathrm{mM}$. This is the first study on the purification and characterisation of PPO from purslane (Portulaca oleracea) that may provide new insight into how to overcome the enzymatic browning.
\end{abstract}

Keywords: Portulaca oleracea; polyphenol oxidase; purification; kinetics; inhibitors.

Practical Applications: Understanding inhibition mechanism of PPO may provide insight into plant browning in food industry.

\section{Introduction}

Polyphenol oxidases (PPO; EC 1.14.18.1) are members of oxidoreductases, belonging to a set of copper containing metalloenzymes, which catalyze the oxidation of a variety of phenolic compounds (Queiroz et al., 2008).

PPOs are widely spread in nature, determined in almost all individual forms of life such as bacteria, protists, fungi, plants and animals. PPO is important as it is responsible for eye, skin, inner ear and hair melanization, as well as browning in fruits and vegetables (Marín-Zamora et al., 2005). Particularly, when a plant gets a damage, cut or bruise, a polymer structure is formed by the the enzyme which oxidizes some phenolic compounds, thus resulting in protection of the plant against microorganisms or insects (Van Gelder et al., 1997). This process causing enzymatic browning of vegetables and fruits is undesirable in food technology because it results in loss of quality. In plant tissues, organoleptic and nutritional modifications occur due to the browning pigments, thus depreciating the quality of the food product (Friedman, 1996; Sanchez-Ferrer et al., 1995). However, the enzymatic browning in some cases is desirable, because in many plant based food products like cocoa, coffee, tea, raisins, figs, dates and prunes, color formation requires PPO activity (Tomás-Barberán \& Espin, 2001).

The inhibition of PPO enzyme and thus prevention of browning is a big challenge for the industry of fruit and vegetable (Mayer, 2006). The purification and characterisation of this enzyme in many plants would lead to biotechnological control of its activity. It should also be clearly stated that enzymes in fruits and vegetables are present in a complex system and thus kinetic studies about the inhibition of purified enzyme does not reflect the effects on the vegetable matrix during food processing (Oey, 2010).

The levels of PPO are well known to be dependent on the species, cultivar, maturity and age (Amiot et al., 1995). PPO characteristics have been studied in a wide variety of plants such as apple (Janovitz-Klapp et al., 1990; Aydin et al., 2015), apricot (Arslan et al., 1998), banana (Ünal, 2007), potato (Lourenço et al., 1992), netle (Gülçin et al., 2005), broccoli (Gawlik-Dziki et al., 2007), peppermint (Kavrayan \& Aydemir, 2001), ispir sugar bean (Sakiroglu et al., 2013), eggplant (Mishra et al., 2012) and Ataulfo mango (Cheema \& Sommerhalter, 2015).

The current study used purslane (Portulaca oleracea) that is a common weed in turfgrass areas, as well as in field crops. It can grow in Asia, Europe, Australia, North America, and Africa (Rashed et al., 2003). It is of importance in medicine as it is used for treatment of headache, burns, and diseases related to the stomach, liver, intestine, cough, shortness of breath, and arthritis. Purslane is also regarded as an important herbal medicine for its use in a cardiac tonic, purgative, muscle relaxant, emollient, and diuretic and anti-inflammatory treatment. Because of possesing high nutritive and antioxidant properties, purslane has been known as a power food (Uddin et al., 2014).

Recent research also shows that purslane, with higher ascorbic acid, alpha-linolenic acid and beta-carotene, has greater nutritional quality compared to the most major cultivated 
vegetables (Liu et al., 2000). Among green leafy vegetables, purslane also found to contain the highest content of vitamin $\mathrm{A}$, as well as possessing vitamin $\mathrm{C}$ and $\mathrm{B}$ complex vitamins like riboflavin, niacin and pyridoxine (Uddin et al., 2012).

This is the first report on the purification and characterisation of purslane PPO in order to understand how the enzymatic browning can be prevented in food technology. In the present study, purslane PPO was purified and characterised by determining the kinetic parameters for three substrates. The inhibition kinetics of PPO purified from purslane were also determined, using both synthetic and natural inhibitors.

\section{Material and methods}

\subsection{Materials and reagents}

The purslane (Portulaca oleracea) used in this study was purchased from a local market in Diyarbakir City, Turkey and frozen at $-25^{\circ} \mathrm{C}$ until used. Catechol was purchased from Merck (Darmstadt, Germany). Ammonium sulfate, Sephadex G-100 gel filtration resin, L-Dopa, polyethylene glycol (PEG), citric acid and all chemicals used in electrophoretic experiments were purchased from Sigma Chem. Co. All chemicals used were of analytical grade.

\subsection{Preparation and extraction of PPO from purslane (Portulaca oleracea)}

Twenty grams of purslane obtained from the local market were homogenized in the extraction solution $(100 \mathrm{ml}$ of $0.1 \mathrm{M}$ phosphate buffer containing 5\% PEG at pH 6.5 and $10 \mathrm{mM}$ ascorbic acid) by using a blender for $5 \mathrm{~min}$. The crude extract samples were centrifuged at $15000 \mathrm{~g}$ for $20 \mathrm{~min}$ at $4{ }^{\circ} \mathrm{C}$. The homogenate was filtered through double layered filter paper. Solid ammonium sulfate $\left(\mathrm{NH}_{4}\right)_{2} \mathrm{SO}_{4}$ was slowly added to the supernatant to get $80 \%\left(\mathrm{NH}_{4}\right)_{2} \mathrm{SO}_{4}$ saturation under cold conditions. Centrifugation at $15000 \mathrm{rpm}$ for $30 \mathrm{~min}$ at $4{ }^{\circ} \mathrm{C}$ was carried out to separate the precipitated proteins. The precipitate proteins were then re-dissolved in a small volume of $0.05 \mathrm{M}$ phosphate buffer ( $\mathrm{pH}$ 6.5) and finally dialyzed at $4{ }^{\circ} \mathrm{C}$ in the same buffer overnight by changing the buffer three times during dialysis. The dialyzed sample is then applied to a stirred ultrafiltration cell (PBGC membrane, Millipore), after which the reduced volume was applied to a Sephadex G-100 column.

\subsection{Gel filtration chromatography}

The gel filtration chromatography was performed by preparing a column $(1.2 \times 70 \mathrm{~cm})$ using Sephadex G-100 and equilibrated with $0.1 \mathrm{M}$ phosphate buffer ( $\mathrm{pH}$ 7.0). The dialyzed and ultrafiltrated enzyme sample was then loaded into the equilibrated column and the elution was carried out at $1.5 \mathrm{~mL} / \mathrm{min}$. The $3 \mathrm{~mL}$ eluates were collected in tubes by a fraction collector. Both protein concentrations and polyphenol oxidase activity of the collected fractions were determined. Then, the active fractions were pooled, ultrafiltrated and stored at $-20^{\circ} \mathrm{C}$ until use in the further experiments. The samples were kept at $4{ }^{\circ} \mathrm{C}$ and then were used as the PPO enzyme source in the following experiments.

\subsection{Enzyme activity}

A spectrophotometric method was used to determine PPO activity on basis of the initial rate of the absorbance increase at $420 \mathrm{~nm}$. Enzyme activity was assayed in $3 \mathrm{ml}$ of reaction mixture consisting of $0.1 \mathrm{ml}$ substrate $(0.1 \mathrm{M} 4$-methylcatechol, catechol or L-Dopa) and $0.1 \mathrm{ml}$ enzyme preparation in $0.1 \mathrm{M}$ phosphate buffer ( $\mathrm{pH}$ 6.5). The activity of PPO was determined by measuring the absorbance at $420 \mathrm{~nm}$ using an GENESYS 10 S UV-Vis spectrometer (Thermo Fisher Scientific, U.S.A.) with a $1 \mathrm{~cm}$ light path quartz cuvette. The blank contained $0.1 \mathrm{ml}$ substrate and $2.9 \mathrm{ml}$ buffer. PPO activity was assayed in triplicate and one enzyme unit represents the amount of enzyme that produces a rise of 0.001 absorbance in one minute at $420 \mathrm{~nm}$.

\subsection{Protein determination}

Bradford (1976) method was used in order to measure protein contents of all samples using bovine serum albumin (BSA) as the standard.

\section{$2.6 \mathrm{pH}$ and temperature effect on PPO activity}

The $\mathrm{pH}$ effect on PPO was tested using $0.1 \mathrm{~mL}$ of enzyme solution, $0.1 \mathrm{~mL}$ of $0.1 \mathrm{M}$ catechol and finally topped-up to $3 \mathrm{~mL}$ with $0.1 \mathrm{M}$ sodium phosphate buffer ( $\mathrm{pH}$ 6.0-9.0) or $0.1 \mathrm{M}$ sodium acetate buffer ( $\mathrm{pH} 3.5-5.5)$. In this buffering range, enzyme activity was measured spectrophotometrically using the procedure described for the PPO activity assay. To determine the effects of temperature and inhibitors on PPO, the optimum $\mathrm{pH}$ corresponding to the highest $\mathrm{PPO}$ activity were used.

PPO activity was determined at different reaction temperatures in the range of $30-80^{\circ} \mathrm{C}$ using catechol as substrate and the buffer was heated to relevant temperature before the assay. The experiments were carried out in triplicate under the standard conditions.

\subsection{Enzyme kinetics and substrate specificity}

Maximum velocity (Vmax) and Michaelis-Menten constant $(\mathrm{Km})$ values of PPO were calculated using the substrates catechol (0.5-18 mM), 4-methylcatechol (0.5-18 mM) and L-Dopa (2-22 mM) under the optimized $\mathrm{pH}$ and temperature conditions. $V \max$ and $\mathrm{Km}$ values of PPO for each substrate were obtained from a plot of $1 / V$ versus $1 /[\mathrm{S}]$ by the method described by Lineweaver \& Burk (1934). Measurements were performed in triplicate.

\subsection{Polyacrylamide gel electrophoresis and zymography}

The PAGE to determine the purity and apparent molecular weight of the PPO in purslane was performed at $4{ }^{\circ} \mathrm{C}$ under mild denaturing conditions using two parallel continuous $7 \%$ gels in Tris-glycine buffer, $\mathrm{pH} 8.9$ following the method of Laemmli (1970). The samples were prepared under partially denaturing conditions by mixing them with a certain voume of loading buffer $1 \%$ SDS, $20 \%$ v/v glycerol and $100 \mathrm{mM}$ Tris, pH 6.8. The enzyme samples were not heated or reduced. After electrophoresis, the protein bands were detected by staining with Coomassie Brilliant 
Blue (CBB) R-250. Following staining, the gels were destained in $7 \%$ acetic acid solution and then photographed. The apparent molecular weight of the enzyme was estimated using prestained molecular weight markers (Sigma SDS7B2): triosephospate isomerase $(26.6 \mathrm{kDa})$, lactic dehyrogenase $(36.5 \mathrm{kDa})$, fumarase $(48.5 \mathrm{kDa})$, pyruvate kinase $(58 \mathrm{kDa})$, lactoferrin $(90 \mathrm{kDa})$, $\beta$-galactosidase (116 kDa), $\alpha_{2}$-macroglobulin $(180 \mathrm{kDa})$.

For zymography of PPO, the gel was incubated in $0.1 \mathrm{M}$ phosphate buffer ( $\mathrm{pH} 7.0$ ) containing $30 \mathrm{mM}$ of catechol for 100 minutes at $50{ }^{\circ} \mathrm{C}$. Staining bands showing PPO activity appeared within $5 \mathrm{~min}$ after adding $1 \mathrm{mM}$ ascorbic acid. The gel was rinsed in distilled water and stored in 30\% ethanol.

\subsection{Effects of inhibitors}

The effects of some inhibitors (sodium azide, citric acid, ascorbic acid) on the activity of purslane PPO were studied. Two constant inhibitor concentrations were tested for measuring PPO activities at with five different substrate concentrations $(1,2,4,6,8 \mathrm{mM}) .1 /[\mathrm{S}]$ and $1 / V$ values derived from PPO activity measurements were used to draw Lineweaver and Burk graphs. Inhibition constants $(\mathrm{K} i)$ of each inhibitor were also estimated from Lineweaver-Burk graphs.

\section{Results and discussion}

\subsection{Optimization of parameters for PPO extraction}

Although PPO has been purified and characterised from many plants, there is no any report describing $\mathrm{PPO}$ from purslane (Portulaca oleracea). In order to overcome negative effects of its phenolic subtrates on the ionic and hydrophobic characteristics (Mayer, 2006), polyethylene glycol (5\%) and ascorbic acid (10 mM) were used to bind the phenols and to reduce quinones to phenolic substrates during extraction, respectively. There were several studies on the PPO purification and characterization using only the precipitated fractions of ammonium sulphate without using chromatographic purification methods (Mishra et al., 2012). The best extraction fraction was achieved with $80 \%\left(\mathrm{NH}_{4}\right)_{2} \mathrm{SO}_{4}$ saturation at $4{ }^{\circ} \mathrm{C}$, followed by gel filtration chromatography.

During extraction, addition of detergents SDS (0.5\%) and triton X-100 $(0.1 \%)$ did not enhance the activity of PPO, showing the absence of strongly membrane-bound forms of PPO. Mishra et al. (2012) also indicated the presence of easily soluble forms of PPO from eggplant.

\subsection{Effect of $p H$ and temperature}

The most commonly used substrates are catechol or phenolic substrates derived from catechol to assess PPO activity in fruits and vegetables (Cheema \& Sommerhalter, 2015). The maximum activity for most of vegetables and fruits is obtained at or near neutral pH value (Sakiroglu et al., 2013). As shown in Figures 1 and 2, optimum $\mathrm{pH}$ and temperature values were determined as $\mathrm{pH} 7.0$ and $50^{\circ} \mathrm{C}$, respectively using the catechol as substrate. The previous studies also raported that optimum pH values were 7.0 for Amasya apple (Oktay et al., 1995), parsley (Lin et al., 2016), Yali pear (Zhou \& Feng, 1991), cocoa (Lee et al., 1991), artichoke (Dogan et al., 2005), Jackfruit (Tao et al., 2013),
pH 7.2 for Barbados cherry (Kumar et al., 2008), pH 5.5 for ispir sugar bean (Sakiroglu et al., 2013) and pH 5.4 for Ataulfo mango (Cheema \& Sommerhalter, 2015), using catechol as a substrate.

Diwakar (2015) also found a similar result with Cinnamomum tamala obtaining the optimum $\mathrm{pH}$ and temperature values of 7.0 and $50^{\circ} \mathrm{C}$, respectively. The optimum temperature for cucumber was also found as $50^{\circ} \mathrm{C}$ (Miller et al., 1990). Although optimum PPO temperatures vary among plants, the extraction methods and the types of substrates used, the activity of PPO is mostly obtained between $30-50{ }^{\circ} \mathrm{C}$. It had been previously shown that different plant types exhibited different optimum temperatures, such as $35^{\circ} \mathrm{C}$ for Chinese parsley (Lin et al., 2016), $30-40^{\circ} \mathrm{C}$ for Hemşin apple (Aydin et al., 2015), $40^{\circ} \mathrm{C}$ for artichoke (Dogan et al., 2005), $45^{\circ} \mathrm{C}$ for chufa corns (Sun et al., 2010), $35^{\circ} \mathrm{C}$ for mamey (Palma-Orozco et al., 2011), $8^{\circ} \mathrm{C}$ for jackfruit (Tao et al., 2013) using catechol as the substrate. It is clear that the optimum temperature of purslane PPO is quite high compared to those reported for most PPO's from other sources.

\subsection{Purification of PPO}

As PPO specific activity increased at subsequent steps of purification, the protein content decreased to a great extent at the final stage. As can be seen in Table 1, the purification steps of purslane PPO include ammonium sulfate precipitation, dialysis and ultrafiltration, and finally gel filtration chromatography by

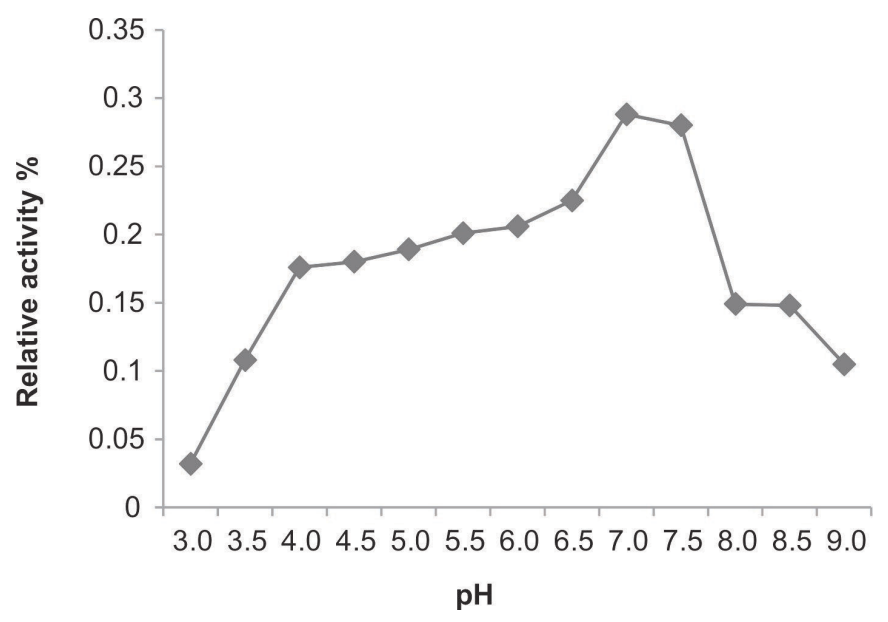

Figure 1. pH effect on PPO activity.

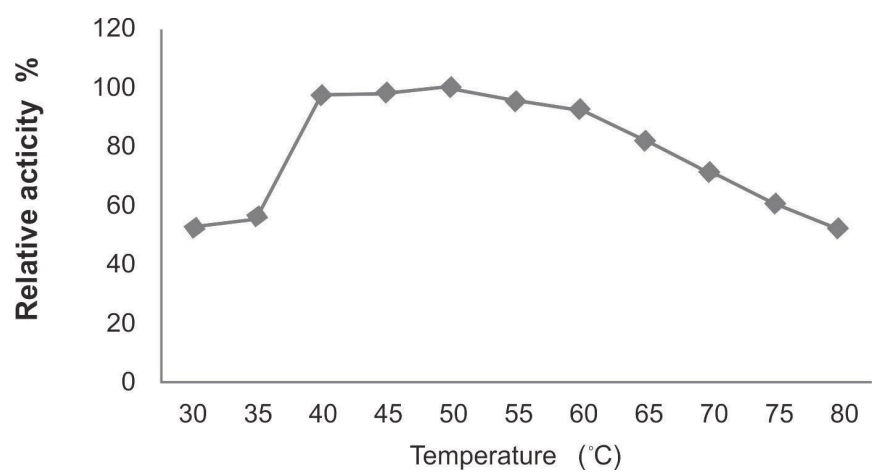

Figure 2. Temperature effect on PPO activity. 
a Sephadex G-100 column. The specific activity of the purified $\mathrm{PPO}$ was determined as $11421 \mathrm{U} / \mathrm{mg}$, with a purification fold of 23.5 and a recovery of 31.3. In the present purification procedure, the loss of total enzyme activity and reduction in the percentage recovery is unavoidable. However, this loss was accompanied by a rise in specific enzyme activity. Moreover, the overall degree of PPO purification was reasonably good compared with that from pear (13.3-fold; Ziyan \& Pekyardimci, 2004), Chinese parsley (6.5-fold; Lin et al., 2016) and Cinnamomum tamala (2.63-fold; Diwakar, 2015). The recovery percentage for purslane PPO obtained in the present study was also better than those in most studies reported previously.

\subsection{Kinetic characteristics of PPO using different substrates}

The variation in the purslane $\mathrm{PPO}$ activity was determined as a function of substrate (catechol) concentration. For determining maximum velocity (Vmax) and Michaelis-Menten constant $(\mathrm{Km})$ values of PPO, the enzyme activities were measured using the concentrations of catechol (0.5-18 mM), 4-methylcatechol (0.5-18 $\mathrm{mM})$ and L-Dopa (2-22 $\mathrm{mM})$ as substrates under optimized $\mathrm{pH}$ and temperature conditions. A plot of $1 / V$ versus 1/[S] was drawn by the method of Lineweaver \& Burk (1934) to calculate $K \mathrm{~m}$ and $V \max$ values of purslane PPO for each substrate. Substrate specificity $(V \max / K \mathrm{~m})$ was also calculated by using the data obtained on the Lineweaver-Burk plot. The Km and Vmax values obtained from the plot analysis of PPO were found as $4.40 \mathrm{mM}$ and $5503 \mathrm{U} / \mathrm{min}$ for catechol, $4.60 \mathrm{mM}$ and $1655 \mathrm{U} / \mathrm{min}$ for L-Dopa and $6.75 \mathrm{mM}$ and $4504 \mathrm{U} / \mathrm{min}$ for 4-methylcatechol, respectively. When the Vmax and $V \max / K m$ values for three substrates were compared, the Vmax and $V \max / K m$ value for catechol was higher than L-dopa and 4-methylcatechol. Catechol was found as the best substrate, followed by 4-methylcatechol and L-Dopa. Therefore, catechol was used as a substrate in the following kinetic studies.

There have been many studies reported on the kinetics of PPO in different plant species, using L-Dopa, 4-methylcatechol and catechol as substrates. The $\mathrm{Km}$ value reflects the enzyme affinity to the substrate. A smaller Km value means higher enzyme affinity to the substrate and vice versa. Km values were found to vary in apricot (Arslan et al., 1998), Hemşin apple (Aydin et al., 2015), mamey (Palma-Orozco et al., 2014), Chinese Toon (Wang et al., 2013) and quince (Yagar \& Sagıroglu, 2002) as $6.6 \mathrm{mM}, 6.8 \mathrm{mM}$, $44 \mathrm{mM}, 10.059 \mathrm{mM}$ and $4.54 \mathrm{mM}$, respectively. When using 4-methylcatechol as the substrate for PPO, $\mathrm{Km}$ values were calculated as $3.14 \mathrm{mM}$ in mango (Palma-Orozco et al., 2014) and $18.2 \mathrm{mM}$ in Jackfruit (Tao et al., 2013). Moreover, when using L-Dopa as the substrate, a $\mathrm{Km}$ value of $17.8 \mathrm{mM}$ was reported in quince (Yagar \& Sagıroglu, 2002).

\subsection{Effect of inhibitor}

The present study is the first report on the inhibition of PPO activity in purslane. The effects of several inhibitors (ascorbic acid, sodyum azide, citric acid) on PPO activities were tested at two constant inhibitor concentrations with five different catechol concentrations $(1,2,4,6,8 \mathrm{mM}) .1 /[\mathrm{S}]$ and $1 / V$ values obtained from these activity measurements were used for drawing Lineweaver and Burk graphs. Moreover, inhibition constants (Ki) of each inhibitor were estimated from Lineweaver-Burk graphs.

It has been reported that the type of inhibition usually depends upon the structural and functional properties of PPOs from different species (Tao et al., 2013). As can be seen in Table 2 and Figure 3, the present study determined that sodium azide and ascorbic acid were noncompetitive type inhibitors for purslane $\mathrm{PPO}$, whereas citric acid resulted in an uncompetetive inhibition. Mishra et al. (2012) reported that ascorbic acid was competitive inhibitor, while sodium azide and citric acid caused mixed inhibition for PPO of eggplant. However, Lin et al. (2016) reported that citric acid was competitive inhibitor for the PPO from Chinese parsley. The most effective noncompetetive inhibition in the present study was displayed by ascorbic acid with the lowest $K i$ value of $0.36 \mathrm{mM}$.

\subsection{Polyacrylamide gel electrophoresis}

Partially denaturing SDS-PAGE showed that the molecular weight of the PPO from purslane was found to be around $163 \mathrm{kDa}$ determined by Commassie staining and by zymogram analysis

Table 1. Purification of PPO from purslane.

\begin{tabular}{|c|c|c|c|c|c|c|}
\hline Steps & $\begin{array}{l}\text { Volume } \\
(\mathrm{ml})\end{array}$ & $\begin{array}{c}\text { Total Protein } \\
(\mathrm{mg})\end{array}$ & $\begin{array}{c}\text { Total Activity } \\
(\mathrm{U})\end{array}$ & $\begin{array}{l}\text { Specific activity } \\
\text { (U/mg protein) }\end{array}$ & $\begin{array}{l}\text { Purification } \\
\text { (fold) }\end{array}$ & $\begin{array}{c}\text { Recovery } \\
(\%)\end{array}$ \\
\hline Crude enzyme & 35 & 36 & 17503 & 486.2 & 1 & 100 \\
\hline $\begin{array}{l}\left(\mathrm{NH}_{4}\right)_{2} \mathrm{SO}_{4} \text { precipitation, dialysis } \\
\text { and ultrafiltration }\end{array}$ & 7.2 & 10.8 & 10575 & 979.2 & 2 & 60.4 \\
\hline Sephadex G-100 & 8 & 0.48 & 5482 & 11421 & 23.5 & 31.3 \\
\hline
\end{tabular}

Table 2. Ki values and inhibition types of inhibitors for purslane PPO.

\begin{tabular}{|c|c|c|c|c|}
\hline Inhibitors & $I(\mathbf{m M})$ & $K i(\mathrm{mM})$ & Average values of $K i(\mathrm{mM})$ & Inhibition type \\
\hline \multirow{2}{*}{ Ascorbic acid } & 0.05 & 0.33 & \multirow{2}{*}{0.36} & \multirow{2}{*}{ Non-competitive } \\
\hline & 0.1 & 0.39 & & \\
\hline \multirow{2}{*}{ Citric acid } & 20 & 0.474 & \multirow{2}{*}{4.47} & \multirow{2}{*}{ Uncompetitive } \\
\hline & 40 & 8.48 & & \\
\hline \multirow{2}{*}{ Sodium azide } & 6 & 3.32 & \multirow{2}{*}{2.76} & \multirow{2}{*}{ Non-competitive } \\
\hline & 8 & 2.21 & & \\
\hline
\end{tabular}


a)

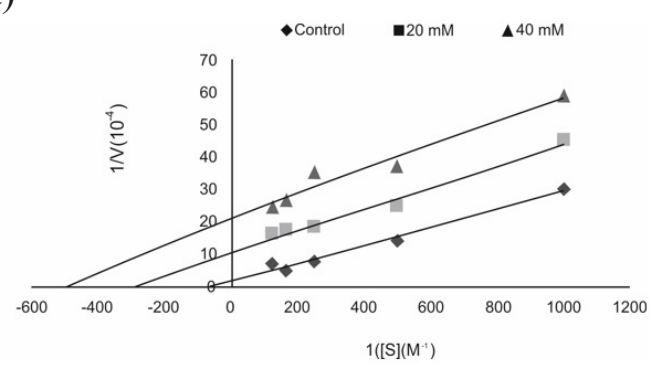

b)

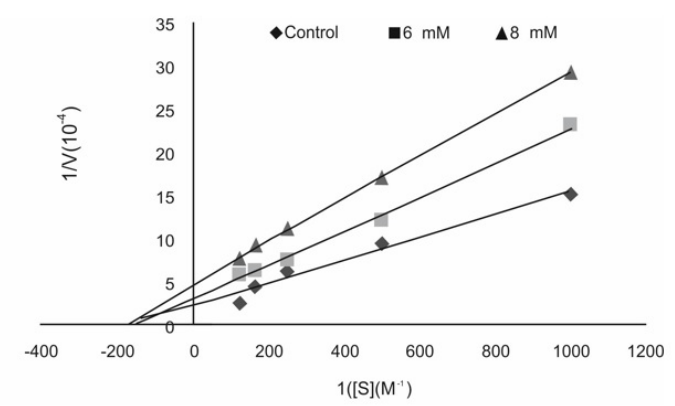

c)

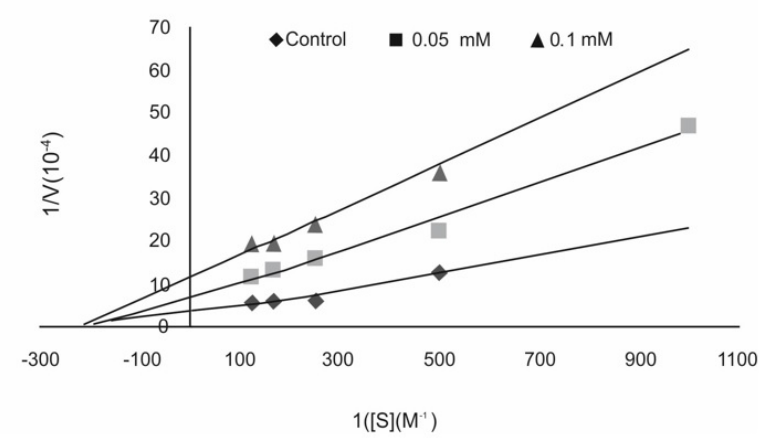

Figure 3. Lineweaver-Burk plots showing inhibition of purslane PPO by citric acid (Part a), ascorbic acid (Part b) and sodium azide (Part c) using catechol as a substrate. showing the presence of PPO activity (Figure 4). The molecular weights of the PPO from various plants were reported as $112 \mathrm{kDa}$ for eggplant (Mishra et al., 2012), $31.5 \mathrm{kDa}$ for mango (Palma-Orozco et al., 2014), multiple bands of 53, 112 and $144 \mathrm{kDa}$ for Ataulfo mango (Cheema \& Sommerhalter, 2015), $82 \mathrm{kDa}$ for atemoya fruit (Chaves et al., 2011).

\section{Conclusions}

In conclusion, the polyphenol oxidase (PPO) is a well-known enzyme that leads to the enzymatic browning of fruits and vegetables. This is normally undesired process and need to be prevented in food technology. From this point of view, PPO from purslane was purified, characterised and the kinetic parameters for three substrates namely, catechol, L-Dopa and 4-methylcatechol were determined. The optimum $\mathrm{pH}$ and temperature values were determined as $\mathrm{pH} 7.0$ and $50{ }^{\circ} \mathrm{C}$, respectively using the catechol as substrate. The apparent molecular weight of PPO from purslane was found to be as high as $163 \mathrm{kDa}$ by partially denaturing SDS-PAGE. The inhibition kinetics of the PPO purified were also determined, using both synthetic and natural inhibitors. Among inhibitors tested, the most effective inhibition was exhibited by ascorbic acid having the lowest $K i$ value. This is the first study on the purification and characterisation of PPO from purslane (Portulaca oleracea) that may provide new insight into how to overcome the enzymatic browning. The present study on the characterisation of PPO from purslane could be further explored using samples from many sources, as it is important to justify the importance of changing localities climates, soils, temperatures and other factors.

\section{Acknowledgements}

This study was funded by DUBAP -15-ZEF-20 project supported by the corresponding author's universty.

b)

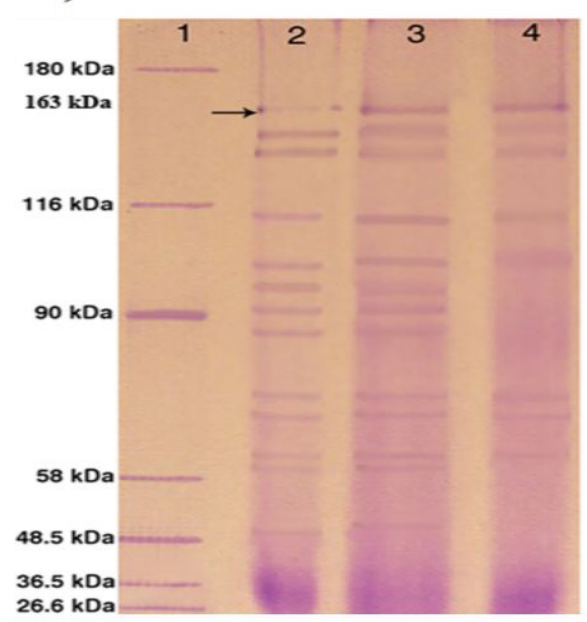

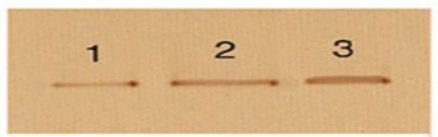

Figure 4. Partially denaturing SDS-PAGE gels were both stained with Coomassie Brilliant Blue (CBB) R-250 (Part a) and were stained for zymography of PPO activity using $30 \mathrm{mM}$ of catechol (Part b). Lane 1 in Part a contains the prestained molecular weight markers (Sigma SDS7B2). Lanes 2, 3,4 in Part a and 1, 2 and 3 in Part b represent crude extract, ammonium sulfate-dialysis and gel filtration samples loaded, respectively. 


\section{References}

Amiot, M., Tacchini, M., Aubert, S., \& Oleszek, W. (1995). Influence of cultivar, maturity stage, and storage conditions on phenolic composition and enzymatic browning of pear fruits. Journal of Agricultural and Food Chemistry, 43(5), 1132-1137. http://dx.doi. org/10.1021/jf00053a004.

Arslan, O., Temur, A., \& Tozlu, I. (1998). Polyphenol oxidase from Malatya apricot (Prunus armeniaca L.). Journal of Agricultural and Food Chemistry, 46(4), 1239-1241. http://dx.doi.org/10.1021/jf970599v.

Aydin, B., Gulcin, I., \& Alwasel, S. H. (2015). Purification and characterization of polyphenol oxidase from hemşin apple (Malus communis L.). International Journal of Food Properties, 18(12), 27352745. http://dx.doi.org/10.1080/10942912.2015.1012725.

Bradford, M. M. (1976). A rapid and sensitive method for the quantitation of microgram quantities of protein utilizing the principle of proteindye binding. Analytical Biochemistry, 72(1-2), 248-254. PMid:942051. http://dx.doi.org/10.1016/0003-2697(76)90527-3.

Chaves, I. R., Ferreira, E. S., Silva, M. A., \& Neves, V. A. (2011). Polyphenoloxidase from atemoya fruit (Annona cherimola mill. Annona squamosa L.). Journal of Food Biochemistry, 35(6), 15831592. http://dx.doi.org/10.1111/j.1745-4514.2010.00508.x.

Cheema, S., \& Sommerhalter, M. (2015). Characterization of polyphenol oxidase activity in Ataulfo mango. Food Chemistry, 171, 382-387. PMid:25308684. http://dx.doi.org/10.1016/j.foodchem.2014.09.011.

Diwakar, S. K. (2015). Purification and characterization of ionically unbound polyphenol oxidase from Cinnamomum tamala syn. Cinnamomum leaves. Applied Food Biotechnology, 2(2), 33-41.

Dogan, S., Turan, Y., Erturk, H., \& Arslan, O. (2005). Characterization and purification of polyphenol oxidase from artichoke (Cynara scolymus L.). Journal of Agricultural and Food Chemistry, 53(3), 776-785. PMid:15686433. http://dx.doi.org/10.1021/jf049053g.

Friedman, M. (1996). Food browning and its prevention: an overview. Journal of Agricultural and Food Chemistry, 44(3), 631-653. http:// dx.doi.org/10.1021/jf950394r.

Gawlik-Dziki, U., Szymanowska, U., \& Baraniak, B. (2007). Characterization of polyphenol oxidase from broccoli (Brassica oleracea var. botrytis italica) florets. Food Chemistry, 105(3), 1047-1053. http://dx.doi. org/10.1016/j.foodchem.2007.05.012.

Gülçin, I., Küfrevioglu, O. I., \& Oktay, M. (2005). Purification and characterization of polyphenol oxidase from nettle (Urtica dioica L.) and inhibitory effects of some chemicals on enzyme activity. Journal of Enzyme Inhibition and Medicinal Chemistry, 20(3), 297-302. PMid:16119202. http://dx.doi.org/10.1080/1475636032000141890.

Janovitz-Klapp, A. H., Richard, F. C., Goupy, P. M., \& Nicolas, J. J. (1990). Kinetic studies on apple polyphenol oxidase. Journal of Agricultural and Food Chemistry, 38(7), 1437-1441. http://dx.doi. org/10.1021/jf00097a001.

Kavrayan, D., \& Aydemir, T. (2001). Partial purification and characterization of polyphenol oxidase from peppermint (Mentha pipetita). Food Chemistry, 74(2), 147-154. http://dx.doi.org/10.1016/ S0308-8146(01)00106-6.

Kumar, V. B., Mohan, K., \& Murugan, K. (2008). Purification and kinetic characterization of polyphenol oxidase from Barbados cherry (Malpighia glabra L.). Food Chemistry, 110(2), 328-333. PMid:26049223. http://dx.doi.org/10.1016/j.foodchem.2008.02.006.

Laemmli, U. K. (1970). Cleavage of structural proteins during assembly of the head bacteriophage T4. Nature, 227(5259), 680-685. PMid:5432063. http://dx.doi.org/10.1038/227680a0.
Lee, P. M., Lee, K. H., Ismail, M., \& Karim, A. (1991). Biochemical studies of cocoa beans polyphenol oxidase. Journal of Food Science and Agri., 55(2), 251-260. http://dx.doi.org/10.1002/jsfa.2740550210.

Lin, H., Ng, A.W.R., Wong, C. W. (2016). Partial purification and characterization of polyphenol oxidase from Chinese parsley (Coriandrum sativum). Food Science and Biotechnology, 25: 91-96.

Lineweaver, H., \& Burk, D. (1934). The determination of enzyme dissociation constants. Journal of the American Chemical Society, 56(3), 658-666. http://dx.doi.org/10.1021/ja01318a036.

Liu, L., Howe, P., Zhou, Y.-F., Xu, Z.-Q., Hocart, C., \& Zhan, R. (2000). Fatty acids and $\beta$-carotene in Australian purslane (Portulaca oleracea) varieties. Journal of Chromatography. A, 893(1), 207-213. PMid:11043602. http://dx.doi.org/10.1016/S0021-9673(00)00747-0.

Lourenço, E. J., Neves, V. A., \& Silva, M. A. (1992). Polyphenol oxidase from sweet potato: purification and properties. Journal of Agricultural and Food Chemistry, 40(12), 2369-2373. http://dx.doi.org/10.1021/ jf00024a009.

Marín-Zamora, M. E., Rojas-Melgarejo, F., García-Cánovas, F., \& GarcíaRuíz, P. A. (2005). Cinnamic ester of D-sorbitol for immobilization of mushroom tyrosinase. Journal of Chemical Technology and Biotechnology (Oxford, Oxfordshire), 80(12), 1356-1364. http:// dx.doi.org/10.1002/jctb.1334.

Mayer, A. M. (2006). Polyphenol oxidases in plants and fungi: going places? A review. Phytochemistry, 67(21), 2318-2331. PMid:16973188. http://dx.doi.org/10.1016/j.phytochem.2006.08.006.

Miller, A. R., Kelley, T. J., \& Mujer, C. V. (1990). Anodic peroxidase isoenzymes and polyphenol oxidase activity from cucumber fruit: tissue and substrate specificity. Phytochemistry, 29(3), 705-709. http://dx.doi.org/10.1016/0031-9422(90)80005-2.

Mishra, B., Gautam, S., \& Sharma, A. (2012). Purification and characterization of polyphenol oxidase (PPO) from eggplant (Solanum melongena). Food Chemistry, 134(4), 1855-1861. PMid:23442630. http://dx.doi.org/10.1016/j.foodchem.2012.03.098.

Oey, I. (2010). Effect of novel food processing on fruit and vegetable enzymes. In A. Bayindirli. Enzymes in fruit and vegetable processing: chemistry and engineering applications (pp. 245-312). Boca Raton: CRC Press.

Oktay, M., Kufrevioglu, I., Kocacaliskan, I., \& Sakirolu, H. (1995). Polyphenol oxidase from Amasya apple. Journal of Food Science, 60(3), 495-499. http://dx.doi.org/10.1111/j.1365-2621.1995.tb09810.x.

Palma-Orozco, G., Marrufo-Hernández, NA., Sampedro, JG., Nájera, H. (2014). Purification and partial biochemical characterization of polyphenol oxidase from mango (Mangifera indica cv. Manila). Journal of Agricultural and Food Chemistry, 62(40), 9832-9840.

Palma-Orozco, G., Ortiz-Moreno, A., Dorantes-Alvarez, L., Sampedro, J. G., \& Najera, H. (2011). Purification and partial biochemical characterization of polyphenol oxidase from mamey (Pouteria sapota). Phytochemistry, 72(1), 82-88. PMid:21087780. http://dx.doi. org/10.1016/j.phytochem.2010.10.011.

Queiroz, C., Lopes, M. L. M., Fialho, E., \& Valente-Mesquita, V. L. (2008). Polyphenol oxidase: characteristics and mechanisms of browning control. Food Reviews International, 24(4), 361-375. http://dx.doi. org/10.1080/87559120802089332.

Rashed, A. N., Afifi, F. U., \& Disi, A. M. (2003). Simple evaluation of the wound healing activity of a crude extract of Portulaca oleracea L. (growing in Jordan) in Mus musculus JVI-1. Journal of Ethnopharmacology, 88(2-3), 131-136. PMid:12963132. http:// dx.doi.org/10.1016/S0378-8741(03)00194-6.

Sakiroglu, H., Yllmaz, E., Erat, M., \& Öztürk, A. E. (2013). Selected properties of polyphenol oxidase obtained from ispir sugar bean. 
International Journal of Food Properties, 16(6), 1314-1321. http:// dx.doi.org/10.1080/10942912.2011.584258.

Sanchez-Ferrer, A., Rodriguez-Lopez, J. N., Garcia-Canovas, F., \& Garcia-Carmona, F. (1995). Tyrosinase: a comprehensive review of its mechanism. Biochimica et Biophysica Acta, 1247(1), 1-11. PMid:7873577. http://dx.doi.org/10.1016/0167-4838(94)00204-T.

Sun, J. Y., You, E. G., Long, X., \& Wang, J. (2010). Biochemical properties and potential endogenous substrates of polyphenoloxidase from chufa (Eleocharis tuberosa) corms. Food Chemistry, 118(3), 799-803. http://dx.doi.org/10.1016/j.foodchem.2009.05.065.

Tao, Y.-M., Yao, L. Y., Qin, Q. Y., \& Shen, W. (2013). Purification and characterization of polyphenol oxidase from jackfruit (Artocarpus heterophyllus) bulbs. Journal of Agricultural and Food Chemistry, 61(51), 12662-12669. PMid:24325285. http://dx.doi.org/10.1021/ jf403828e.

Tomás-Barberán, A. F., \& Espin, J. C. (2001). Phenolic compounds and related enzymes as determinants of quality in fruits and vegetables. Journal of the Science of Food and Agriculture, 81(9), 853-876. http:// dx.doi.org/10.1002/jsfa.885.

Uddin, M. K., Juraimi, A. S., Ali, M. E., \& Ismail, M. R. (2012). Evaluation of antioxidant properties and mineral composition of Portulaca oleracea (L.) at different growth stages. International Journal Molecule Science, 13(8), 10257-10267. PMid:22949859. http://dx.doi.org/10.3390/ijms130810257.
Uddin, M. K., Juraimi, A. S., Hossain, M. S., Altaf, M., Nahar, U., Ali, M. E., \& Rahman, M. M. (2014). Purslane weed (Portulaca oleracea): a prospective plant source of nutrition, omega-3 fatty acid, and antioxidant attributes. TheScientific WorldJournal, 2014, 951019951019. PMid:24683365. http://dx.doi.org/10.1155/2014/951019.

Ünal, M. Ü. (2007). Properties of polyphenol oxidase from Anamur banana (Musa cavendishii). Food Chemistry, 100(3), 909-913. http:// dx.doi.org/10.1016/j.foodchem.2005.10.048.

Van Gelder, C. W. G., Flurkey, W. H., \& Wichers, H. J. (1997). Sequence and structural features of plant and fungal tyrosinases. Phytochemistry, 45(7), 1309-1323. PMid:9237394. http://dx.doi.org/10.1016/S00319422(97)00186-6.

Wang, C., Zhang, J.-F., Zhang, Y., \& Cheng, B. (2013). Characterization and inhibitors of polyphenol oxidase from Chinese Toon. Food Biotechnology, 27(3), 261-278. http://dx.doi.org/10.1080/0890543 6.2013 .811688 .

Yagar, H., \& Sagıroglu, A. (2002). Partially purification and characterization of polyphenol oxidase of Quince. Turkish Journal of Chemistry, 26, 97-103.

Zhou, H. W., \& Feng, X. (1991). Oxidase from yali pear (Pyrus bretschneideri). Journal of the Science of Food and Agriculture, 57(3), 307-313. http://dx.doi.org/10.1002/jsfa.2740570302.

Ziyan, E., \& Pekyardimci, Ş. (2004). Purification and characterization of pear (Pyrus communis) polyphenol oxidase. Turkish Journal of Chemistry, 28, 547-557. 